\title{
Editorial - the transnational history of international institutions
}

\author{
Glenda Sluga \\ Department of History, University of Sydney, NSW 2006, Australia \\ E-mail: glenda.sluga@sydney.edu.au
}

In the globalized world of the twenty-first century, international institutions are attracting belated historical interest as significant transnational sites of study. This is in stark contrast to the twentieth century, when historians were relatively uncurious about the nature of transnational experiences and subjectivities, the institutionalization of transnational practices and ideas, and, in Chris Bayly's elegant phrase, 'the sentiment of internationalism'. ${ }^{1}$ Over the last decade, however, the League of Nations in particular has benefitted from serious new studies of its operation in the interwar period. ${ }^{2}$ Of the twentieth-century international organizations that are still with us, the United Nations, UNESCO, the International Labour Organization, and the International Council on Archives, are each engaged in turning historical attention towards their own operations and the wider significance of their institutional pasts. Their approaches and results have varied. In each case, inspired archivists and bureaucrats are forging links with academics in search of a past that anchors the internationality of their respective organizations more solidly in the present. So, what do historians have to gain from this exercise?

The articles by Daniel Laqua, Todd Shepard, and David Webster published in this issue of the Journal of Global History are witness to the rich harvest that is already being reaped by the new historical interest in international institutions. As significantly, their reproduction here is the result of a conference entitled 'Towards the Transnational History of International Organizations: Methodology/Epistemology', held in April 2009 at Kings College, Cambridge, and organized by the International Scientific Committee for the UNESCO History Project. This committee comprised a group of historians (including me) who were brought together in 2006 under the auspices of the UN's specialized agency, UNESCO, in the wake of its sixtieth anniversary celebrations, and of the precedents set by earlier collaborations between UNESCO and the Centre for History and Economics at the University of Cambridge. ${ }^{3}$ The committee's scholar members, in time-honoured UNESCO fashion,

1 Taken from Professor Chris Bayly's opening remarks at 'Transnational History of International Organizations: Methodology/ Epistemology’ conference, King's College, Cambridge, April 2009.

2 At the forefront of this research is a new international network on the History of the League of Nations, coordinated by Professors Susan Pedersen (Columbia), Patricia Clavin (Oxford), Corinne A. Pernet (St. Gallen), and Davide Rodogno (Graduate Institute, Geneva). Other new international networks include the History of International Organizations Group, founded in Geneva by Professors Sandrine Kott (University of Geneva), Davide Rodogno, and Daniel Palmieri (International Committee of the Red Cross); and Women, Internationalisms, and Gender, set up by Kathryn Sklar, Megan Threlkeld, and me (see http://wigblog.binghamton.edu/ (consulted 8 April 2011).

3 The important UNESCO figure in these collaborations was Dr Jens Boel, UNESCO's chief archivist. 
informally represented the regions of the globe. The further away from the transnational networks of the world's longer-established and better-endowed universities, the more difficult it was to find historians with the research infrastructure that might have brought them to the study of international rather than national institutions. ${ }^{4}$ Thus, among the concerns of the committee historians was the desire to provide the conditions under which the study of international institutions by a younger cohort might prosper, and to bring a relatively marginalized discussion about the past of international institutions such as UNESCO into conversation with the new, or revived, disciplinary interest in transnational and global histories.

It seems almost too obvious that the study of international institutions would adopt a transnational approach. Political scientists have long shown interest in institutions such as UNESCO, as the axis of what was in the post Second World War period a newly constituted and self-consciously international society. ${ }^{5}$ And yet histories of international institutions have tended to downplay or ignore the transnational setting, context, and implications of these institutions. Conventionally, UNESCO's archives have been mined for their illumination of either specialized national narratives, or the story of the origins of UNESCO as narrowly linked to the League of Nations' Paris-based Intellectual Cooperation Organization, or the London-based discussions among Allied ministers of education during the Second World War. The organization of the 2009 Cambridge conference reinforced an argument that Emma Rothschild has made in other discussions of UNESCO's history and historical work: that the national focus of archives has been one of the major sticking points of a new transnational history, and that the archives of international organizations, some of them located inside national archives, are an extraordinarily fertile, undervalued, underutilized, and endangered source of historical research of the transnational kind. ${ }^{6}$ Promoting the transnational history of international institutions was the committee's way of stimulating the use of these archives, arguing for the insertion of international institutions into thick intersecting histories of social and political influences across geopolitical spaces, and encouraging the recontextualization of international institutions and ideas in the social history of twentieth-century internationalisms.

The 2009 Cambridge conference usefully presented a cross-section of the range of historical work already being done on the transnational history of international institutions in the twentieth century, most of it emerging from Germany, Switzerland, and England. ${ }^{7}$ In this work, as in the articles that we chose for this issue, transnationalism tends to mean two

4 The original committee members were Robert Frank (France), Ilya Gaiduk (Russia), Mohieddine Hadhri (Tunisia), Akira Iriye (Japan), José Paradiso (Argentina), Emma Rothschild (United Kingdom), JeanFrançois Sirinelli (France), Glenda Sluga (Australia), Romila Thapar (India), Ibrahima Thioub (Senegal), and Thomas Weiss (United States of America). The conference was organized by a section of the committee. For more on the committee and the UNESCO History Project, see http://www.unesco.org/ archives/new2010/en/scientific_committe.html (consulted 8 April 2011).

5 See, for example, the references to UNESCO in Hans Morgenthau, Politics among nations: the struggle for power and peace, New York: Alfred A. Knopf, 1948.

6 See Emma Rothschild, 'The archives of universal history', Journal of World History 19, 3, 2008, pp. 375-401.

7 Summaries of the presentations can be found at the UNESCO History Project site. See, in particular, Madeleine Herren, who oversees a University of Heidelberg-based and European Union-funded research consortium studying Asia and Europe in a global context; Patricia Clavin from Oxford University, who is playing a pivotal role in the resuscitation of the history of the League of Nations; and Sandrine Kott, who is connected to the burgeoning historical work on the International Labour Organization. 
(usually overlapping) things: a perspective from which to view identities and policies, and an object of study, by virtue of which, as Sunil Amrith has commented, international institutions become the ideal case study for analysing transnational connections, flows, journeys, and identities. ${ }^{8}$

Daniel Laqua's article on the history of the League of Nations' International Institute of Intellectual Cooperation takes us back to the interwar period in order to construct an alternative social and intellectual genealogy for later twentieth-century manifestations of internationalism. Laqua tracks the dominant motifs that linked the circulation of people, ideas, and practices: an imperative to global order, and the search by intellectuals and social scientists for identity and status. Along the way, he unearths the overlapping interest of fascist and liberal governments in the internationalist ambitions of the League (so that the International Institute of Educational Cinematography in Rome was funded by Fascist Italy, and the Nazi German state participated enthusiastically in scientific internationalism and international journals). Ultimately, ideas were the tools with which intellectuals organized themselves internationally, asserting their status as experts in a new world order of incommensurate empires, nations, and the politically and culturally underrepresented. Each of the essays collected confirms the intimate and long-standing relationship between the ambitions of Western (although not only Western) social scientists and the workings of international institutions such as the League and the United Nations. Intellectuals have been crucial to the functioning of international institutions, contributing their expertise to, and establishing their status in, a larger world of transnational networking, colonial relationships, decolonization, and state-building.

David Webster's article tracks the journey of experts and ideas across the geopolitical spaces of Canada, Bolivia, and Indonesia. It complicates, and thereby clarifies, our understanding of the persistence of colonialism and a late nineteenth-century imperialist mindset, in the practices of mid-twentieth-century international institutions. The Technical Assistance programme of the late 1940s and 1950s, which has often been told as an American story, is, as Webster illustrates, fundamentally an international story to be told through the organs and operations of the United Nations, and the rise of the economic expert. Significantly, even in that international version, Technical Assistance resonates with North American dollar-diplomacy imperialism and the influence of white settler societies, such as Canada, in the validation of a specific modernizing internationalism. Webster reveals the extent to which mid-twentieth-century agents of international institutions and internationalism easily accommodated late nineteenth-century conceptions of race, empire, and nationalism in their discourses of modernization. In particular, he underlines the purchase of economic models and norms and normative bureaucratic and modernizing practices among the representative 'native' state-builders of decolonizing and postcolonial nations, as well as among the all too eager social scientists who were flown in from the metropoles of modernity. International institutions, we find paradoxically, were critical to the history of nation-state-building.

Finally, Todd Shepard's article opens up a radically new way of connecting the chronologies, geographies, and archives of international, national, and imperial pasts. It excavates

8 These were Sunil Amrith's closing remarks. See also Sunil Amrith and Glenda Sluga, 'New histories of the UN', Journal of World History, 19, 3, 2008, pp. 251-74. 
the links between ethnological research in 1930s Mexico, undertaken by social scientists under the auspices of the League, and France's redeployment of that knowledge in its fight against Algerian nationalism. The catalyst in this relationship was the Paris-based UNESCO, or more specifically the numerous conferences that it sponsored in the 1940s and 1950s as part of its legislated commitment to anti-racism. In an imaginative tour de force, Shepard explores how, in the 1950s, the governor-general of Algeria, Jacques Soustelle, and the key civilian members of his cabinet, drew inspiration from Mexican (and, more indirectly, Soviet) interwar policies that avowedly anti-racist anthropologist-ethnographers had defined and overseen. It is the UNESCO conferences that effectively bring the social sciences and the history of the interwar period into the post-war field of French policy-making. In this article, the transnational study of international institutions draws new national and imperial relationships and trajectories across the longue durée of the twentieth century.

In Sunil Amrith's words, international organizations such as UNESCO have acted as 'a site and a resource: a place to stake claims on the world stage ... as the source of symbolic tools - languages, images, norms, standards - which can be turned into claims of entitlement, despite the vast inequalities of power and influence that of course characterize every international or transnational institution'. 9 If there is a new transnational history of international institutions then, like the articles collected here, it illuminates the intersecting twentieth-century histories of ideas and politics, of empires, nations, and international institutions. It draws crooked lines connecting East and West, North and South, through the international hubs and fora of international institutions. It brings together a variety of strands of historical methodology - the study of ideas, institutions, intellectuals, bureaucrats, subjectivities, and 'publics'. Future transnational histories of international institutions might invite reflection, too, on the conceptualization of international public opinion and of an international public sphere: that is, an intellectual and ideological space competing and intersecting with the more familiar national public opinions and public spheres that historians tend to study. They might raise new questions about how national public opinions are generated transnationally, about the transnational influence of national campaigns, and might generate new genealogies of global civil society. As we see in this volume, they are already taking us further into the social and cultural histories of international institutions.

This list of possibilities and practices in the 'international turn' is by way of returning to the question with which I started out this introduction: what do historians have to gain from the transnational study of international institutions? The kinds of answer inspired by the Cambridge conference, and by the collaboration between academics and archivists, circle around the alternative chronologies suggested by a focus on international institutions, and around the possibilities opened up by 'seeing beyond the state' through the life of international organizations. They allow us to revisit old topics such as the Cold War and decolonization, resuscitate older historical obsessions such as international society, and imagine 'the sentiment of internationalism'. They add to the study of international institutions a transnational lens, which will hopefully bring into clearer and closer view not only men but women, and not only Europe but also a whole other international world.

9 Sunil Amrit, closing remarks at 'Transnational History of International Organizations: Methodology/ Epistemology’ conference, King’s College, Cambridge, April 2009. 